\title{
EVALUATION OF VERTEBRAL HIDDEN FRACTURES IN PATIENTS WITH PROXIMAL FEMORAL FRACTURES
}

\author{
AVALIAĈ̃O DE FRATURAS VERTEBRAIS OCULTAS EM PACIENTES COM FRATURAS \\ DO FEMUR PROXIMAL
}

\author{
EVALUACIÓN DE FRACTURAS VERTEBRALES OCULTAS EN PACIENTES \\ CON FRACTURAS DEL FEMMUR PROXIMAL
}

André Luís Sebben ${ }^{1}$, Guilherme Schlusaz Morais ${ }^{1}$, Álynson Larocca Kulcheski ${ }^{2}$, Pedro Grein Del Santoro², Marcel Luiz Benato², Xavier Soler i Graells ${ }^{1}$, Marcelo Abagge ${ }^{2}$

\begin{abstract}
Objective: To evaluate the Spine Deformity Index (SDI) and serum levels of vitamin D in patients surgically treated for proximal femur fracture and its relationship with osteoporosis. Methods: Between August and November 2013, patients older than 50 years-old with surgical fracture of the proximal femur by low-energy trauma underwent radiographic evaluation of the spine and the vitamin $\mathrm{D}$ levels, and enquired about diagnoses and previous treatment of osteoporosis. Results: Sixty-six patients met the inclusion criteria. The mean age was 78 years; the average level of vitamin D was $19 \mathrm{ng} / \mathrm{mL}$. The SDI ranged between zero and 25, with a mean of 8.2. Eighty percent of these patients had never been treated for osteoporosis. Of the patients analyzed, $89.3 \%$ had insufficient levels of vitamin D. Of these, $68.1 \%$ had also SDI above 5 , and only one fifth of them had any treatment for osteoporosis. Statistical significance was found between age and levels of vitamin D as well as age and SDI. Gender was not predictive of the vitamin $D$ levels or the amount of hidden spine fractures. The season of the year had no direct influence on vitamin $D$ levels. Conclusions: Hospitalized patients with surgical fractures of the proximal femur had a higher SDI associated with vitamin D insufficiency, with osteoporosis most often untreated, which results in delayed spinal fractures diagnosis of spinal fractures and increased risk of new fractures.
\end{abstract}

Keywords: Vitamin D; Spinal fractures; Osteoporosis; Osteoporotic fractures; Femoral fractures.

\begin{abstract}
RESUMO
Objetivo: Avaliar o índice de deformidade espinhal (SDI) e níveis séricos de vitamina $D$ em pacientes tratados cirurgicamente por fratura do fêmur proximal e a relação desses dados com osteoporose. Método: Entre agosto e novembro de 2013, pacientes com mais de 50 anos e fratura cirúrgica do fêmur proximal por trauma de baixa energia foram submetidos à avaliação radiográfica da coluna vertebral e do nível sérico de vitamina $D$ e questionados sobre diagnóstico e tratamentos prévios para osteoporose. Resultados: Sessenta e seis pacientes satisfizeram os critérios de inclusão. A média de idade foi 78 anos e o nível sérico médio de vitamina $D$ foi 19 ng/mL. O SDI variou entre zero e 25, com média de 8,2. Oitenta por cento desses pacientes nunca receberam tratamento para osteoporose. Dos pacientes analisados, 89,3\% tinham níveis insuficientes de vitamina D. Destes, 68,1\% também tinham índice de deformidade espinhal acima de 5, e somente um quinto deles realizou algum tipo de tratamento para osteoporose. Houve significância estatística entre a idade e a concentração de vitamina D e entre a idade e o SDI. O sexo não foi preditivo dos níveis de vitamina D ou da quantidade de fraturas ocultas de coluna. A época do ano não teve influência sobre o nível de vitamina $D$ dos pacientes. Conclusão: Pacientes internados com fratura de fêmur proximal apresentam índice de deformidade espinhal elevado associado à insuficiência de vitamina $D$, com osteoporose na maioria das vezes, não tratada, o que se traduz em diagnóstico tardio de fraturas de coluna e aumento no risco de novas fraturas.
\end{abstract}

Descritores: Vitamina D; Fraturas da coluna vertebral; Osteoporose; Fraturas por osteoporose; Fraturas do fêmur.

\section{RESUMEN}

Objetivo: Evaluar el índice de deformidad de la columna vertebral (SDI) y los niveles séricos de vitamina D en los pacientes tratados quirúrgicamente por fractura del fémur proximal. Evaluar la relación de estos datos con la osteoporosis. Métodos: Entre agosto y noviembre de 2013, los pacientes con más de 50 años y con fractura quirúrgica del fémur proximal por un traumatismo de baja energía fueron sometidos a la evaluación radiográfica de la columna vertebral y a la determinación del nivel sérico de vitamina $D$ y se les pregunto sobre el diagnóstico y los tratamientos previos para la osteoporosis. Resultados: Sesenta y seis pacientes cumplieron los criterios de inclusión. La edad promedio fue de 78 años la media del nivel sérico de vitamina D fue de $19 \mathrm{ng} / \mathrm{mL}$. El SDI osciló entre zero y 25, con una media de 8,2. El ochenta por ciento de estos pacientes nunca fueron tratados para la osteoporosis. De los pacientes analizados, el 89,3\% tenían niveles insuficientes de vitamina $D$. De ellos, el 68,1\% tenían índice de deformidad de la columna superior a 5 y solamente una quinta parte recibió algún tratamiento para la osteoporosis. Se ha verificado significación estadística entre la edad y el nivel de vitamina D y entre la edad y el SDI. El sexo no fue predictivo de los niveles de vitamina D o la cantidad de fracturas de columna ocultas. La época del año no tuvo influencia en la concentración de vitamina $D$. Conclusión: Los pacientes hospitalizados con fracturas femorales proximales tienen una alta tasa de deformidad de la columna asociada con la insuficiencia de vitamina $D$, además de osteoporosis no tratada, lo que resulta en un retraso en el diagnóstico de las fracturas de la columna vertebral y un mayor riesgo de nuevas fracturas.

Descriptores: Vitamina D; Fracturas de la columna vertebral; Osteoporosis; Fracturas osteoporóticas; Fracturas del fémur.

1. Hospital de Clínicas da Universidade Federal do Paraná, Curitiba, Paraná, Brazil.

2. Hospital do Trabalhador, Curitiba, Paraná, Brazil.

Study conducted at the Orthopedic Service of the Hospital doTrabalhador, Universidade Federal do Paraná, Curitiba, Paraná, Brazil.

Correspondence: Rua Coronel Pedro Scherer Sobrinho, 152, ap 174. Torre Imbuia, Cristo Rei, Curitiba, Paraná, Brasil. 80050-470. andresebben@gmail.com 


\section{INTRODUCTION}

Fractures of the vertebral bodies are one of the main characteristics of osteoporosis. Their consequences are well known, and include strong and incapacitating pain, loss of the physiological spinal curvatures, and loss of height, as well as the use of Health System resources. The prevalence of spinal fractures increases with age; they are present in up to $26 \%$ of individuals over 50 years of age and in up to $50 \%$ of women over 75 years of age.

The presence of a spinal fracture is a risk factor for other spinal fractures and fractures in other skeletal regions, representing a more significant predictive factor than bone mineral density and metabolic markers of bone turnover. ${ }^{1}$

Fractures most commonly associated with bone insufficiency include those affecting the region of the proximal third of the femur which, due to their severity, are usually treated surgically. Patients with these fractures, when admitted for hospital treatment, are investigated for other insufficiency fractures associated with low energy trauma, such as distal radius fractures and spinal fractures. ${ }^{2}$ Most fractures of the thoracic and lumbar spine are peculiar as, unlike the appendicular skeleton and cervical spine, their occurrence is often not discovered immediately. Therefore, it is necessary to perform an imaging test for the diagnosis, using an evaluation method that allows us to quantify this vertebral collapse.

Considering that the elderly population has a higher risk of fractures caused by low energy trauma, and that insufficiency fractures are a consequence of osteoporosis, the aim of this study is to assess the presence of hidden thoracolumbar spinal fractures, using the spine deformity index in patients over 50 years of age treated surgically for proximal femoral fractures, and their correlation with serum vitamin $\mathrm{D}$ and with the previous diagnosis of osteoporosis.

\section{METHODS}

This is a cross-sectional prospective epidemiologic study. The inclusion criterion were patients aged over 50 years and proximal femoral fractures submitted to surgical treatment caused by low energy trauma treated at the Hospital do Trabalhador, associated with the Universidade Federal do Paraná, a tertiary hospital specialized in trauma care, located in the city of Curitiba, state of Paraná, Brazil. Patients with pathologic fractures caused by tumors, multiple trauma victims, patients who have already undergone surgical treatment of some spinal disease in the thoracic or lumbar region, individuals with congenital deformities of the thoracic or lumbar spine, and individuals with juvenile or infantile scoliosis were excluded. The selected patients who met the criteria for inclusion and agreed to take part in the study were offered an informed consent form, which the patients signed in agreement. The study was approved by the hospital's ethics committee on $7 / 27 / 2013$ under report number 336.790 .

After signing the consent form, the patients were referred for a radiologic examination of the thoracic and lumbar spines in the anteroposterior (AP) and lateral views in a $43 \mathrm{~cm}$ by $45 \mathrm{~cm}$ radiographic chassis. The $\mathrm{x}$-rays were taken with the patient positioned in dorsal decubitus for the AP view and in lateral decubitus for the lateral view. All the radiologic parameters were measured by a single author, accustomed to this measurement, obtaining the spine deformity index (SDI). A blood sample was also taken to determine serum calcidiol levels.

The SDI described by Genant et al. ${ }^{3}$ is a tool that assesses both the number of fractured vertebrae and the severity of the fractures. This method enables the evaluation of prevalent fractures in an initial evaluation and incident fractures in serial examinations. Each vertebra evaluated, from $T 4$ to $L 4$, receives a score relating to its morphological appearance. A vertebra classified with a grade 1 fracture exhibits a reduction of up to $25 \%$ in the height of one of the walls, while grade 2 represents a reduction between 25 and $40 \%$ and grade 3 , more than $40 \%$. (Figure 1) The sum of the results classifies the spine with an index, which represents the SDI.
Direct research with the use of a questionnaire was used to investigate whether the patient had had a previous diagnosis of osteoporosis, undergone bone densitometry, or received clinical treatment for osteoporosis, and which treatment. It was also ascertained whether the patient had a previous fracture of the distal radius, the spine or the contralateral proximal femur.

All the patients received guidance and answers to their queries regarding the risk of osteoporosis and actions to prevent the disease. The patients who were diagnosed with spinal fractures and/or vitamin D deficiency (calcidiol) were referred to the Spinal Pathology Outpatient Clinic of the Hospital do Trabalhador for clinical follow-up.

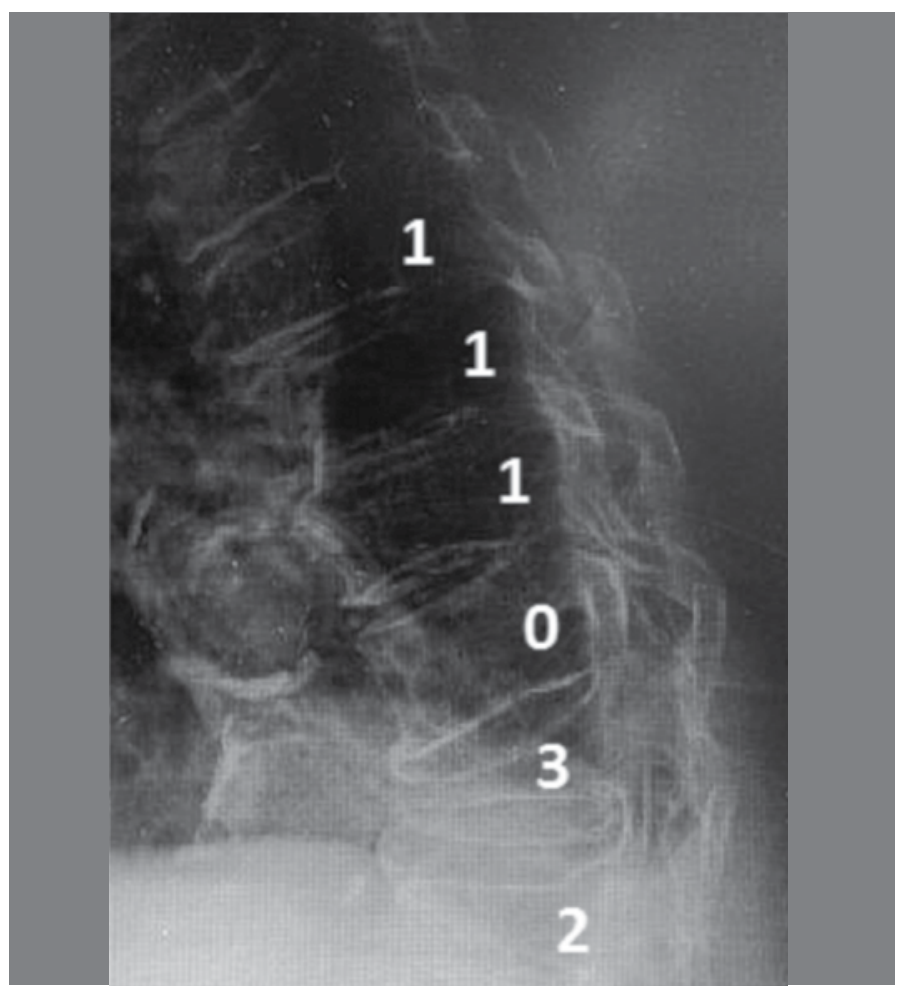

Figure 1. Detail of lateral spine radiograph evidencing classification of the scores of the vertebrae in terms of height reduction.

\section{RESULTS}

This study involved 66 patients: 45 women (68\%) and 21 men (32\%). The average age of the patients in the study was 78 years, with standard deviation of 8.6, ranging from 53 to 95 years, as shown in Figure 2.

The serum vitamin D (Figure 3) levels averaged $19 \mathrm{ng} / \mathrm{mL}$, with a maximum of $70 \mathrm{ng} / \mathrm{mL}$ and a minimum of a value below $4 \mathrm{ng} / \mathrm{mL}$, undetectable by the methods used. It is worth remembering that values below $32 \mathrm{ng} / \mathrm{mL}$ are considered insufficient and indicate the need for oral supplementation. ${ }^{4}$

The SDI ranged between zero and 25, averaging 8.2. It should be emphasized that when the SDI exceeds a score of five, the risk of further fractures increases considerably. When it exceeds a score of eight, the risk of further fractures reaches a plateau. ${ }^{5}$

Among the patients with SDI above five, a group consisting of 45 patients $(68.1 \%)$ of the total, only six patients $(13.3 \%)$ had a previous diagnosis of osteoporosis, and just four of these six patients had undergone bone densitometry.

Of all the patients in question, $83 \%$ never had access to the densitometry scan, and $80 \%$ had never been treated for osteoporosis.

Only three cases had already sustained a previous proximal femoral fracture, and only one of these patients was having treatment for osteoporosis 
Fifty-nine of the 66 patients (89.3\%) had lower-than-normal levels of vitamin D. (Figure 4) Of these, $68.1 \%$ had a spine deformity index score above 5 , and only $19.6 \%$ were undergoing any type of osteoporosis treatment. (Figure 5)

Relating age versus serum vitamin D levels using Spearman's nonparametric test, with a p-value $=0.03692$, there was a statistically significant inverse relationship, i.e., the higher the age, the lower the vitamin $D$ serum levels. The correlation coefficient is provided by: $p=0.2574$. (Figure 6)

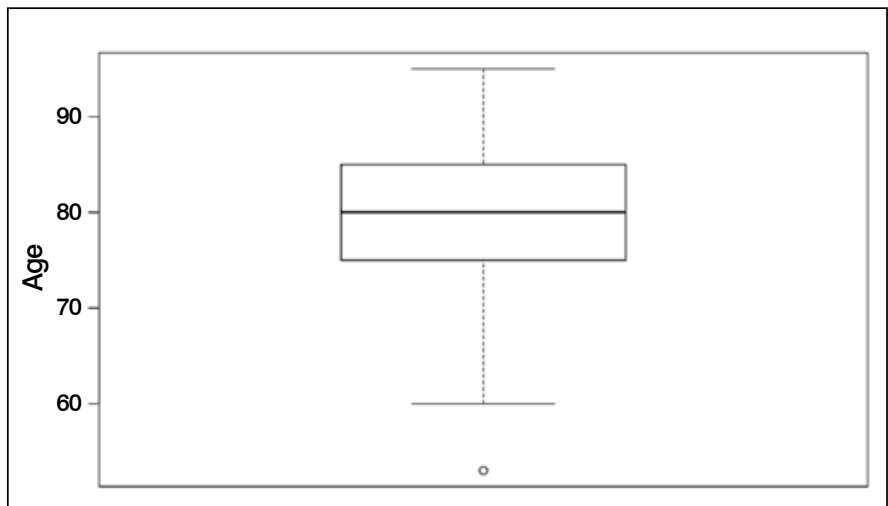

Figure 2. Distribution of ages of the study sample, maximum and minimum age, mean and standard deviation.

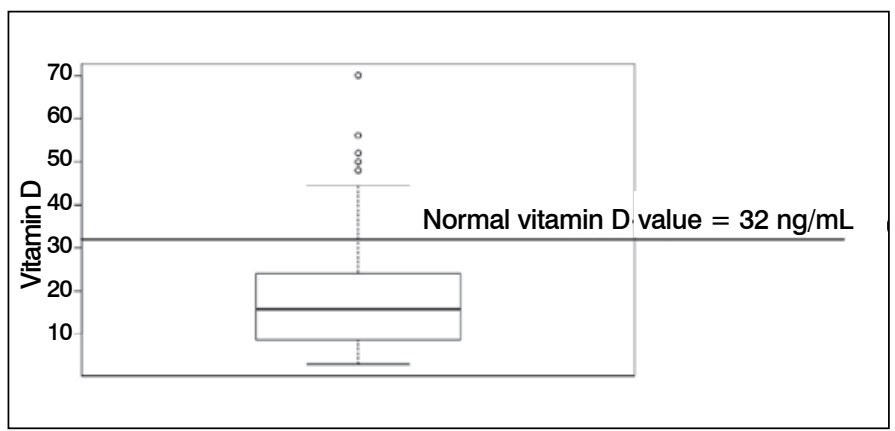

Figure 3. Distribution of levels of vitamin D found, maximum and minimum values, mean and standard deviation, and comparison with target minimum value.

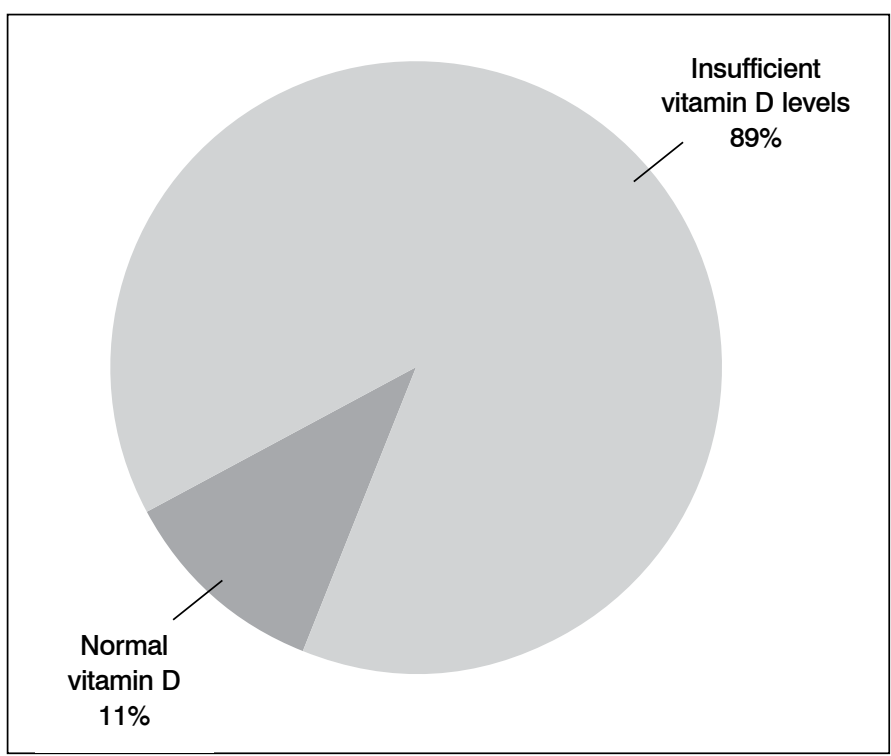

Figure 4. Comparison between percentage of patients with adequate levels of vitamin $D$ and insufficient levels.
The same inverse relationship was obtained when relating age versus SDI. With a p-value $=0.01944$, Spearman's nonparametric test showed that the higher the age, the higher the spine deformity index. The correlation coefficient is provided by: $p=0.2870$.

Using the Wilcoxon test to verify whether there is a relationship between the amount of vitamin $D$ found in male versus female patients, there was no significant difference, as the $p$-value $=0.5042>0.05$.

The same hypothesis of difference between the sexes was tested in relation to the SDI, and once again there was no significant relationship in this sample ( $p$-value $=0.08573>0.05$ ).

Spearman's nonparametric test was used to ascertain whether patients with vitamin $D$ deficiency really had more spinal deformities, and there was inverse correlation between these variables. In other words, the patient with low vitamin $D$ levels really had more spinal abnormalities. The coefficient of this relation was 0.2666 (Figure 7).

There was no statistically significant difference in mean vitamin $D$ values between the months of the year. We should point out that although this difference may exist, owing to the sample size, it may not have been evident.

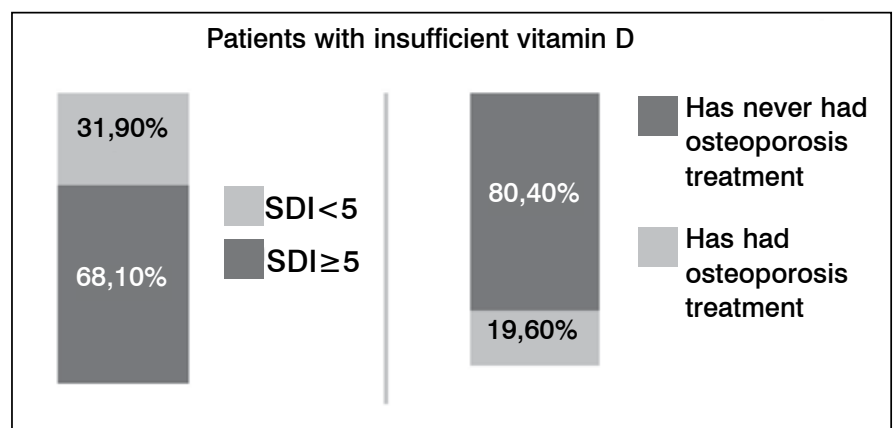

Figure 5. Distribution of percentages of accentuated spinal deformity and absence of osteoporosis treatment among patients with lower-than-normal levels of vitamin $\mathrm{D}$

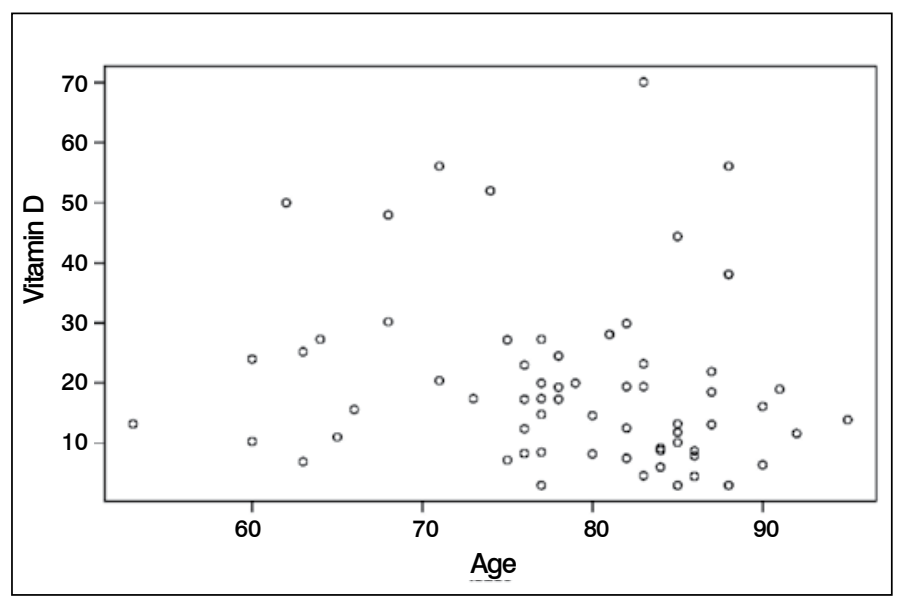

Figure 6. Distribution of age $x$ levels of vitamin $D$, showing concentration of low values of vitamin $\mathrm{D}$ with increased age.

\section{DISCUSSION}

In our trauma service, we provide medical care to a population with limited access to salutary education measures, tests and even to appointments with a physician. The quantity of undiagnosed and consequently untreated osteoporosis patients drew our attention. It was expected that the higher the age, the greater the spinal deformity and the lower the levels of serum vitamin D. A noteworthy aspect was the quantity of patients with critical levels of this nutrient who were not receiving any follow-up care or treatment. Another important point of the study was the relationship between vitamin $D$ and insufficiency fractures of the spine. Dawson-Hughes et al. ${ }^{6}$ had 


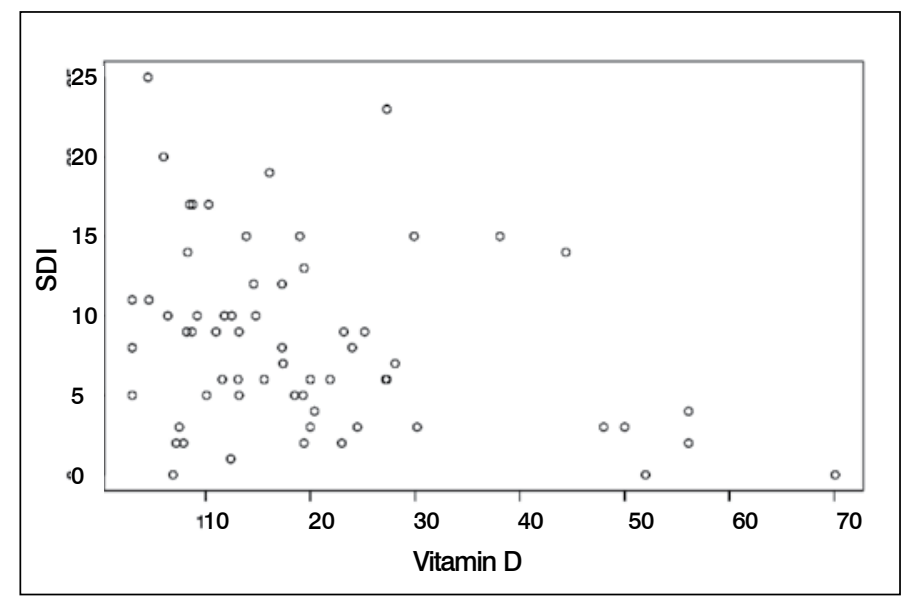

Figure 7. Distribution of vitamin D x spine deformity index (SDI), showing relationship of low values of calcidiol and high SDI scores.

already shown a direct correlation between vitamin $\mathrm{D}$, bone density and consequent fractures. Cranney et al. ${ }^{7}$ in a review in 2007, also confirmed this relationship.

Kimlin et al., ${ }^{8}$ in a study conducted in 2014 involving 1002 individuals, proved that there is a relationship between vitamin $D$ levels, amount of exposure to sunlight, and time of the year. However, we were unable to demonstrate in the study that vitamin $D$ levels really do fall in the colder months. This difference may become evident in a larger sample. Another possibility is that the habits that lead to minimum exposure to sunlight in our population are constant throughout the year. In other words, although the amount of solar radiation increases, older individuals remain prone to insufficient exposure to sunlight.

As regards the methods, routine densitometry at a trauma center with high turnover rates would not be possible, hence the reason for the choice of the Genant method, which is fast, easy and involves low costs. Genant et al. ${ }^{3}$ described the semi-quantitative method that assesses the thoracic and lumbar spines for research into spinal deformity caused by compression fractures, which are present in patients with osteoporosis. Since then, several comparative analysis studies have been conducted between the diagnostic methods of spinal fractures due to osteoporosis, indicating the superiority of reproducing Genant's method ${ }^{9,10}$, which was used in this study. In the study by Roux et al., ${ }^{1}$ which analyzed the prognostic importance of the spine deformity index, the progression of fractures was noted in number and degree in a population of postmenopausal women.
It was observed that the value of each fracture gradation (1, 2 or 3 ) had distinct equivalence. Two grade 1 fractures had the same value as a grade 2 fracture, and two grade 2 fractures had the same value as the sum of a grade 1 fracture and a grade 3 fracture. Accordingly, it was possible to assess the result of the treatment through the serial analysis of the spine radiographs. When the SDI exceeds a score of five, the risk of further fractures increases considerably. When it exceeds a score of eight, the risk of further fractures reaches a plateau. This occurs because the assessment is performed on 13 vertebrae (from T4 to L4), so at a given time, there will naturally be no more vertebrae to be fractured. With the rise in this index, the risk of further fractures would be virtually zero.

The vitamin $\mathrm{D}$ level has a role in the mineralization and consequent prevention of fractures that is well established in literature. ${ }^{6,11} \mathrm{~A}$ meta-analysis of the effect of vitamin $D$ and the reduction of the risk of spinal and femoral fractures demonstrated a significant reduction of fractures in the group that had adequate levels of vitamin $D$, being of greater importance in postmenopausal women. ${ }^{7}$ Calcidiol is the form of vitamin $\mathrm{D}$ deposit and can be determined. It should remain between 32 to $100 \mathrm{ng} / \mathrm{mL}$ of serum. ${ }^{4}$ This test served to prove that behind the radiologic alterations found in the patient, there lies an underlying systemic disease that, in most cases, is not being treated.

Besides the radiographic evaluation and measurement of vitamin $D$, to conclude the tripartite process of our study, we applied a simple and objective questionnaire that could be answered by older individuals without major difficulties. This questionnaire covered the patient's history, in relation both to previous treatments and to previous fractures. It is important to emphasize that we recorded details such as the patients' addresses and telephone numbers, so that other prospective studies can be conducted as a follow-up of this sample.

\section{CONCLUSION}

Older individuals who have sustained fractures in the proximal third of the femur due to low energy trauma should have their spines assessed and be investigated for vitamin D insufficiency, as fractures in the vertebral bodies have shown themselves to be very frequent and associated with lower-than-normal levels of this nutrient. The evaluation using SDI had good applicability, and should be used in future evaluations for the diagnosis of these vertebral fractures. Prevention, diagnosis and early intervention should be prioritized, in order to avoid an increase in the morbimortality of this patient group.

All authors declare no potential conflict of interest concerning this article.

\section{REFERENCES}

1. Roux C, Fechtenbaum J, Kolta S, Briot K, Girard M. Mild prevalent and incident vertebral fractures are risk factors for new fractures. Osteoporos Int. 2007;18(12):1617-24.

2. Russel TA. Intertrochanteric fractures. In: Bucholz RW, Heckman J, Court-Brown CM, Tornetta Paul 3rd, editors. Rockwood and Green`s fractures in adults. 7th ed. Philadelphia: Lippincott Williams \& Wilkins; 2009. p. 492-3.

3. Genant HK, Wu CY, van Kuijk C, Nevitt MC. Vertebral fracture assessment using a semiquantitative technique. J Bone Miner Res. 1993;8(9):1137-48.

4. Hollis BW. Assessment of vitamin D status and definition of a normal circulating range of 25-hydroxyvitamin D. Curr Opin Endocrinol Diabetes Obes. 2008;15(6):489-94.

5. Crans GG, Genant HK, Krege JH. Prognostic utility of a semiquantitative spinal deformity index. Bone. 2005:37(2):175-9.

6. Dawson-Hughes B, Harris SS, Krall EA, Dallal GE. Effect of calcium and vitamin D supplementation on bone density in men and women 65 years of age or older. N Engl J Med. 1997;337(10):670-6.
7. Cranney A, Horsley T, O'Donnell S, Weiler H, Puil L, Ooi D, et al. Effectiveness and safety of vitamin D in relation to bone health. Evid Rep Technol Assess (Full Rep). 2007;(158):1-235.

8. Kimlin MG, Lucas RM, Harrison SL, van der Mei I, Armstrong BK, Whiteman DC, et al. The contributions of solar ultraviolet radiation exposure and other determinants to serum 25-hydroxyvitamin D concentrations in Australian adults: the AusD Study. Am J Epidemiol. 2014:179(7):864-74.

9. Grados F, Roux C, de Vernejoul MC, Utard G, Sebert JL, Fardellone P. Comparison of four morphometric definitions and a semiquantitative consensus reading for assessing prevalent vertebral fractures. Osteoporos Int. 2001;12(9):716-22

10. Genant HK, Jergas M, Palermo L, Nevitt M, Valentin RS, Black D, et al. Comparison of semiquantitative visual and quantitative morphometric assessment of prevalent and incident vertebral fractures in osteoporosis The Study of Osteoporotic Fractures Research Group. J Bone Miner Res. 1996l;11(7):984-96.

11. Melton LJ 3rd, Atkinson EJ, O'Fallon WM, Wahner HW, Riggs BL. Long-term fracture prediction by bone mineral assessed at different skeletal sites. J Bone Miner Res. 1993;8(10):1227-33. 